Dr. R. B.Campbell and Dr. Neil T. Kerr were unanimously elected Representative Members of Council for 1929-30, and Dr. Wm. M. Buchanan was unanimously elected Divisional Secretary.

Dr. R. B. Campbell was unanimously elected Chairman of the Division for the year $1929-30$.

The following candidates after ballot were admitted as ordinary members of the Association:

William Ronald Dodds Fairbairn, M.A., M.B., Ch.B.Edin., Dipl.Psych., Lecturer in Psychology, Edinburgh University ; Psychologist, Jordanburn Nerve Hospital : 18, Lansdowne Crescent, Edinburgh.

Proposed by Prof. G. M. Robertson, Drs. Neil T. Kerr and Wm. M. Buchanan.

Gwyneth Duncan Love, M.B., Ch.B.Edin., Resident Clinical Assistant, Royal Edinburgh Hospital for Mental Disorders, Morningside, Edinburgh. Proposed by Prof. G. M. Robertson, Drs. D. M. B. Lothian and M. E. McLaren.

Douglas Robert MacCalman, M.B., Ch.B.Glasg., Assistant Medical Officer, Argyll and Bute District Mental Hospital, Lochgilphead.

Proposed by Drs. Donald Ross, Neil T. Kerr and Wm. M. Buchanan.

The changes in lunacy and mental deficiency administration arising out of the Local Government (Scotland) Act, 1929, were considered, and after some discussion it was agreed to leave the whole matter in the hands of the Divisional Committee of Management, with a watching brief. It was further agreed that in the event of any local authority putting forward administrative proposals of an unsatisfactory nature, members would at once communicate the facts to the Divisional Secretary.

The Secretary submitted a letter from the General Secretary intimating that the Mental Nursing Advisory Committee to the General Nursing Councils should be reappointed annually. It was unanimously agreed that the Scottish section of this Committee should be reappointed, viz., Prof. G. M. Robertson, Drs. John Keay, T. C. Mackenzie, Douglas McRae and Wm. M. Buchanan.

Members were shown over the hospital by Dr. Hotchkis and his assistant.

Members were kindly entertained to lunch at the hospital, and on the motion of Dr. Campbell, the Renfrew District Board of Control and Dr. Hotchkis were cordially thanked for their hospitality and for the arrangements made in connection with the meeting.

On the meeting reassembling, Dr. Peters gave a résumé of the results of treatment of general paralysis at Dykebar by malaria and tryparsamide and demonstrated illustrative cases. An interesting discussion followed, in which Drs. D. K. Henderson, C. C. Easterbrook, W. McAlister, W. D. Chambers, W. McWilliam, J. H. Skeen, Aidan Thomson and McLachlan took part.

A vote of thanks to the Chairman terminated the business of the meeting, after which members were kindly entertained to tea at Mid-Dykebar by Dr. and Mrs. Hotchkis.

\title{
IRISH DIVISION
}

The Summer Quarterly and Clinical Meeting of the Irish Division was held at Limerick Mental Hospital, by kind invitation of Dr. P. J. Irwin, on Thursday, July 4, 1929 .

Fourteen members were present. Dr. R. R. Leeper, Chairman of the Division, presided.

Apologies for unavoidable absence were received from Lt.-Col. W. R. Dawson, M.D., Drs. J. O'Conor Donelan, D. L. Kelly, J. C. Martin, T. A. Greene, H. R. C. Rutherford, Alexis FitzGerald and O. Felix McCarthy.

Members assembled before luncheon at Dr. Irwin's house and a party was formed to visit the Shannon works. An expert guide conducted members over the whole of this colossal undertaking.

At the luncheon Dr. IRwiN, the host, in a speech welcomed the guests to Limerick Mental Hospital and City.

Immediately after the luncheon Dr. Leeper was presented with a silver 
salver from the members of the Irish Division, " to mark their affection and esteem on the conclusion of a long period as Hon. Secretary and upon his election as first Chairman of the Division." In making the presentation Dr. M. J. NolaN said that it was with more than ordinary feelings of pleasure that, on behalf of the Irish Division of the Royal Medico-Psychological Association, he had the privilege to ask Dr. Leeper - their late Secretary and their first Chairman - to accept a token of their affectionate regard and high esteem. Like those remarkable persons whom the newspapers recorded as having lived through three or four reigns, he, the speaker, could look back on the reigns of four secretaries of the Irish Division; Drs. Maziere Courtenay, Arthur Finegan, W. R. Dawson and R. R. Leeper, and had seen the advent of the latter's successor. Sitting in that Hospital where they were that day he could look back to forty-six years ago, when Dr. Courtenay was Superintendent there. From being a junior colleague of Sir James Crichton-Browne at the West Riding of York Asylum Dr. Courtenay had come to Limerick as the pioneer of much-needed reform in the administration of the lunatic asylums of this country. Many of those present knew and appreciated how much Dr. Courtenay did as an Inspector of Lunatics. It was there that he, the speaker, gained from Dr. Courtenay his first knowledge of insanity; and whatever measure of success he had had was due in no small degree to his instruction, advice and example. Dr. Finegan was Secretary at a period when a small body of men tried to stir up not only in the ranks of the profession, but in the lay mind, a wider knowledge of the insane and of the need for betterment in their conditions. He was indeed a Victorian pioneer. Then came Dr. W. R. Dawson, who had consolidated and increased the activities of the Division in a very marked degree, handing it over to Dr. Leeper in a state of Edwardian prosperity. All present know how that happy state was dispelled by the war years of extrinsic and intrinsic upheaval-a never-to-be-forgotten period of vicissitudes. Then it was that they had the good fortune to have in Dr. Leeper a Secretary who took up arms to lead them through a sea of troubles. When the springs of interest in the affairs of the Division seemed about to dry up, Dr. Leeper had replenished them by the steady, constant stream of his endeavour-a generous source which had never failed. No one was better fitted for the task which then faced him. He had done the collar-work of a long hill-climb, and so rendered splendid service to the Irish Division, and consequently to the Royal MedicoPsychological Association as a whole. They all appreciated his tireless zeal ; they had experienced the benefit of his wide sympathy in their varied interests, and they had enjoyed above all that radiant buoyancy which constituted his genial personality. They were fortunate, too, that in all that concerned the well-being of the Division, he had had the valuable and willing help of Mrs. Leeper, who had been their charming hostess on many occasions. To her they owed, and willingly tendered, their expression of grateful appreciation.

Dr. LEEPER, in replying, said that he was quite unable to express adequately his feelings of gratitude for the kindness he had received. He referred to the periods of stress through which their country had passed, and stated that, were it not for the unfailing help and encouragement he had always received from the members, the Division could not have held together.

Dr. J. Mills proposed a vote of thanks to Dr. Irwin for the generous hospitality they had received, and this was seconded by Dr. KEENE.

The members then proceeded to the Mental Hospital for the Quarterly, following which was a Clinical, Meeting.

The minutes of the last meeting were read, approved and signed by the Chairman.

The following candidate was duly elected an ordinary member of the Association : Elizabeth Maud Mahony, M.B., B.Ch., B.A.O., N.U.I.

Proposed by Dr. T. P. Conlon, seconded by Dr. D. L. Kelly and Dr. Stanley Blake.

The Chairman then gave an account of the visit of the Deputation of the Association to the General Nursing Council of England and the views which they placed before that body. He regretted that their efforts had been unsuccessful, and that the English General Nursing Council still refused to recognize, for Registration, the Association's Nursing Certificate. Nevertheless there was a steady increase in the number of nurses taking the Royal Medico-Psychological Nursing Certificate. He felt that all this was only of passing interest to the Irish Division as, happily, the Irish General Nursing Council had recognized the Association's certificate for registration. 
Dr. P. Grace said that in his experience eligible nurses frequently refused to pay the $£ 22 s$. fee necessary for registration.

Other members spoke in similar strain with regard to the attitude of the English General Nursing Council, but it was the feeling of the meeting that the Division need not take further action in this matter.

The Chairman then informed the meeting of the death of one of their numberDr. Christopher Costello-since the last meeting of the Division. A motion of sympathy was passed in silence, the members standing. The Secretary was instructed to convey the sympathy of the Division to the relatives in their sad bereavement.

Following upon a discussion, it was agreed to hold the next Quarterly and Clinical Meeting in the Royal College of Physicians, Kildare Street, Dublin, on Thursday, November 7, 1929, and it was urged that an effort should be made to provide clinical material or papers, so that all these meetings should maintain their clinical status.

Dr. MrLls then kindly invited the Division to Ballinasloe for the Spring Meeting to be held in April, 1930.

This terminated the proceedings.

\section{DIVISIONAL CLINICAL MEETINGS.}

\section{Limerick Mental Hospital.}

A Clinical Meeting of the Irish Division was held at the above hospital on Thursday, July 4, 1929. Dr. R. R. Leeper, Chairman of the Division, presided.

Dr. C. B. MoLony read the clinical record of the case of a moral defective with a history of encephalitis lethargica.

Female patient, C. M-, æt. I3, admitted June 18, 1929.

History of acute attack of encephalitis.- The patient, living in the south of Ireland, was taken ill on February 18, 192I, when aged 5, with shivering, drowsiness and headache, most intense behind her eyes. She was seen (by Dr. D. Corboy) on February $2 \mathrm{x}$, when her temperature was $102^{\circ} 6^{\circ} \mathrm{F}$., the pulse 120 . She was asleep, and could only be roused with difficulty; when the eyes were open the conjunctiva were seen to be injected-the typical pink eye of influenza. She was very constipated, necessitating enemata, but had no incontinence of urine. There was a watery discharge from the nose. She had muscle twitchings-very marked in the eyelids. When roused she answered questions slowly but intelligently, but was profoundly asleep again within a few minutes. Her temperature fell to $99^{\circ} \mathrm{F}$. and her pulse to 95 by February 24, but the lethargy seemed to increase, the patient only being awake when roused to take food. Dr. W. M. Crofton was then consulted, and it million $B$. influenza antigen were given on the morning of March 2 under the skin of the hip; her temperature was then $99^{\circ}$ and the pulse 95. She was asleep again a short time after the injection. At the end of six hours she woke up quite bright and cheerful; the temperature had fallen to $974^{\circ}$ and the pulse to 76 . She remained awake four hours. On March 4 she remained awake from 9 a.m. to 6 p.m. The drowsiness then gradually increased again until, on March ro, she was given 21 million. She slept for three hours and woke up bright and gay. Next day, however (March Irth), a reaction appeared. She slept a goud deal. She complained of headache. The temperature rose to $994^{\circ} \mathrm{F}$., the pulse to IIs. The discharge from the nose came on again, and the conjunctivæ were injected. These symptoms passed away by the next day, and she remained normal in every way. She was given a few more increasing doses of antigen.

The rapid relief after the first dose, just as significant diagnostically as the focal and general reaction after the second dose, makes it certain to our minds that the influenza bacillus was the causative organism. Unfortunately, owing to the distance from a laboratory no satisfactory bacteriological examination of the nasal discharge could be made.

The antigen used was made from a recent growth on human blood-agar which was not killed by heat, so that nothing was done which would in any way reduce its potency. 